\title{
DESCRIPTIONS OF ALL FEMALE STAGES \\ OF THE MAPLE MEALYBUG, PHENACOCCUS ACERIS \\ (HEMIPTERA: COCCOIDEA: PSEUDOCOCCIDAE), WITH NOTES ON ITS BIOLOGY
}

\author{
M. Bora Kaydan ${ }^{1}$, A. Neşet KilinçeR ${ }^{2}$ and Takumasa Kondo ${ }^{3}$ \\ ${ }^{1}$ Imamoglu Vocational School, Çukurova Üniversity, Adana, 01330, Turkey \\ E-mail:borakaydan@yyu.edu.tr \\ ${ }^{2}$ Ankara University, Faculty of Agriculture, Plant Protection Department \\ 06110, Ankara, Turkey; E-mail: kilincer@agri.ankara.edu.tr \\ ${ }^{3}$ Corporación Colombiana de Investigación Agropecuaria (CORPOICA) \\ Centro de Investigación Palmira, Calle 23, Carrera 37, Continuo al Penal, Palmira, Valle \\ Colombia; E-mail: takumasa.kondo@gmail.com
}

The adult female and all wingless nymphal stages of the maple mealybug, Phenacoccus aceris (Signoret), are redescribed and illustrated. The second-instar nymphs of both males and females produce a felt-like cover, which is secreted by numerous dorsal tubular ducts. A key is also provided to separate wingless immature stages of Ph. aceris, based on morphological features. The life cycle and biology of the mealybug on three different plant hosts, i.e., Acer negundo L., A. pseudoplatanus L. (Aceraceae) and Fraxinus excelsior L. (Oleaceae) over two years is presented and compared. Ph. aceris displayed similar developmental rates on all three host plants. Ph. aceris has one generation per year in Ankara, Turkey, and overwinters as third-instar females and male prepupae and pupae in hidden places on the trunk and branches of its host plants. The longest nymphal stage on all host plant species was the third-instar female and the male prepupa and pupa stage. In both sexes there were differences in the periods of occurrence of each developmental stage amongst years that may relate to variation in field temperatures.

Key words: insect growth rate, immature stages, urban entomology.

\section{INTRODUCTION}

The maple mealybug, Phenacoccus aceris (Signoret) (Hemiptera: Coccoidea: Pseudococcidae), has a Holarctic distribution (BeN-Dov et al. 2015). This mealybug is regarded as being of European origin and was recorded for the first time in Turkey by BodenheIMER (1953). DüzGüneş (1982), ÖNCüER et al. (2001) and KAYDAN et al. $(2004,2005)$ recorded this species in Ankara and other parts of Turkey on various ornamental plants and regarded it as a pest species.

Phenacoccus aceris has been recorded from more than 100 host plants (BeN-Dov et al. 2015), and is occasionally an important pest on ornamental and fruit trees (generally on Malus, Acer and Fraxinus) (Newstead 1903, Bartlett 1978, Kosztarab \& Kozár 1988, Danzig 1990, Kosztarab 1996), particularly 
in urban areas. It lives on trunks, branches and leaves of its hosts (DüZgüNEŞ 1982, Kosztarab \& Kozár 1988, Danzig 1990, Kosztarab 1996). Phenacoccus aceris is a bisexual species and has one generation per year (DüzGüNEş 1982, Kosztarab \& Kozár 1988, Danzig 1990, Kosztarab 1996). Females of Ph. aceris have three instars while the males have four instars (two mobile instars plus a prepupa and a pupa).

Although the direct effects of feeding by this mealybug are usually considered unimportant, the production of honeydew provides a medium for sooty mould fungi to grow, turning the trees black, reducing the rate of leaf light-transmission and the rate of photosynthesis. Furthermore, the maple mealybug is also important because of its transmission capability of some important plant viruses (e.g., grapevine leaf roll-associated viruses-1 and -3 (GLRaV-1 and -3) (SForZa et al. 2003).

Descriptions and illustrations of the adult female have been provided by Ferris (1950), Ter-Grigorian (1973), Tereznikova (1975), Paik (1978), Kosztarab and Kozár (1988), Danzig (1990) and by Kosztarab (1996). While the number of circuli is generally a stable feature for most mealybug species, the number of circuli may vary in maple mealybug from two to five in some populations (Danzig 1990). However, the populations from Armenia (Ter-GriGorian 1973), Central Europe (Kosztarab \& Kozár 1988) and North America (Kosztarab 1996) commonly have two circuli, as was reported for Turkey by DüZGüNEş (1982). Descriptions and illustrations of the first-instar nymph, and second- and third-instar female nymphs were given by TER-GrIGORIAN (1973). Although the description and illustration of the second-instar nymph by TeRGrigorian (1973) shows no differentiation between males and females, she mentioned that there were oral collar tubular ducts distributed on all surfaces of the nymphs that she examined. Despite this previous study, here we provide detailed descriptions of the immature stages of female instars and of the second-instar male in order to facilitate quick identification of most stages of the maple mealybug. The correct identification of the growth stages of this mealybug is essential in timing control programs. The development of efficient control programs also requires information on the period of occurrence of each developmental stage in the population. Although the biology of $P h$. aceris has been previously studied (DüzGüneş 1982, Kosztarab \& KozÁr 1988, Danzig 1990, Kosztarab 1996), there are no detailed data on the occurrence of each developmental stage of this species in the field.

The purpose of this study was therefore to supply an identification key to separate the wingless nymphal instars of Ph. aceris based on microscopic morphological characteristics, and to provide information on the field phenology of the developmental stages of Ph. aceris in Ankara, Turkey. Data gen- 
erated in this study will aid in the development of control programs against the maple mealybug.

\section{MATERIAL AND METHODS}

Field sampling - Infested trees of each of the three species namely; Acer negundo L., A. pseudoplatanus L. (Aceraceae) and Fraxinus excelsior L. (Oleaceae) from three different areas in urban Ankara, Turkey, were marked. The three hosts were around 25-30 years old, 4-5 m tall and not pruned regularly. Observations to determine the developmental stages and to investigate the duration of each stage were made from mid November 2001 to late November 2003. Samples were taken weekly between February and December, and every two weeks between December and February. Three different sampling methods were used during the year because of the biology of the maple mealybug: i) leaf samples were collected from the end of May to mid November, when the mealybug is feeding on the leaves, ii) branch and stem samples from mid November to mid February, when the mealybug overwinters in aggregations in bark cavities, or in other hidden places on old branches and stems, and iii) one year-old twig samples from mid February to the end of May, when mature third-instar nymphs and adult females are usually found feeding in these twigs. The samples were taken from the lower parts of the trees at a height of $2-3 \mathrm{~m}$ from the ground. Infested parts were sampled randomly from different sides of the trees, placed in plastic bags and taken to the laboratory for slide mounting, as described below, and for biological studies.

Slide mounting - Specimens were sorted under a dissecting microscope in the laboratory and mounted on glass slides using the method of Kosztarab and KozÁr (1988). Between 20 and 100 specimens were slide-mounted each week throughout the year from each of the three tree species.

Morphological examination - Only slide-mounted specimens of Ph. aceris collected from F. excelsior were used to describe the immature stages of this mealybug. A phase-contrast microscope (Nikon E200) with a micrometer eyepiece was used to take measurements and prepare illustrations. Body size (length and width), length of antennae, length of legs (and leg parts), cerarian setae, apical setae, and the width of anal ring of each developmental stage were measured. The morphological description of each immature stage was based on twenty specimens. Moulting specimens (from second- to third-instar) were used in order to accurately determine the morphological characters of male and female second-instar nymphs. Hitherto, no morphological differentiation between males and females of the second-instar nymphs of Ph. aceris were known, and were considered to be undistinguishable (TER-Grigorian 1973). The morphological terms and methods for measurements followed those of Gullan (2000). Illustrations were prepared by M. B. Kaydan.

Phenology of mealybugs - The phenology of the mealybug was studied on all three host tree species. Slide-mounted specimens from each of the three hosts were studied under a compound microscope, and at least 50 specimens were checked weekly to determine the developmental stage using the diagnostic features described in the taxonomic section of this paper. The size of each immature stage of the maple mealybug was determined by measuring the body length and width, and the antennal length of 20 of the above 50 specimens. The occurrence of each developmental stage in the population was determined as being from the time each growth stage was first detected until the last individual of that stage was observed in each population. 


\title{
RESULTS AND DISCUSSION
}

\author{
Phenacoccus aceris (Signoret, 1875)
}

Pseudococcus aceris Signoret, 1875: 329. Syntypes, female, FRANCE, Chambery (Savoie) on Carpinus, Tilia and Aesculus; on 'sycomore' (= sycamore) or 'erable' (= Acer pseudoplatanus), no locality indicated. Deposited in Vienna: Naturhistorisches Museum Wien, Austria.

Pseudococcus aesculi Signoret, 1875: 330. Lectotype female, by subsequent designation BenDov \& Matile-Ferrero (1995): 251, FRANCE, Paris, on Aesculus hippocastanum. Deposited in Vienna: Naturhistorisches Museum Wien, Austria. Synonymized by BeNDov \& Matile-Ferrero (1995): 250.

Pseudococcus hederae Signoret, 1875: 332. Syntypes, female, FRANCE, Herault, Montpellier, on 'lierres' (= Hedera helix). Deposited in Vienna: Naturhistorisches Museum Wien, Austria. Synonymised by Ben-Dov \& Matile-Ferrero (1995): 251.

Pseudococcus platani Signoret, 1875: 334. Lectotype female, by subsequent designation BeNDov \& Matile-Ferrero (1995): 252, FRANCE, Haute-Savoie, Annecy, on Platanus orientalis. Deposited in Vienna: Naturhistorisches Museum Wien, Austria. Described: Synonymised by Ben-Dov \& Matile-Ferrero (1995): 251.

Pseudococcus ulmi Douglas, 1888: 124. Syntypes, female, ENGLAND, London, on Ulex europaeus. Deposited in London: The Natural History Museum, England, UK. Synonymised by Newstead (1903): 176.

Phenacoccus polyphagus Borchsenius, 1949: 213. Lectotype female, by subsequent designation Danzig (1980): 124, RUSSIA, Primor'ye Kray, Vladivostok, on ash tree [= Fraxinus excelsior]. Deposited in St. Petersburg: Zoological Museum, Academy of Science, Russia. Synonymised by DANzIg (1970): 1016.

Phenacoccus gorgasalicus Hadzibejli, 1960: 304. Syntypes, female, GEORGIA, Tbilisi, Botanical Gardens, on Quercus hartwissiana and Q. iberica. Deposited in St. Petersburg: Zoological Museum, Academy of Science, Russia, and Tbilisi: Plant Protection Institute, Republic of Georgia. Synonymised by Danzig (2003): 331.

Phenacoccus prunicola Borchsenius, 1962: 232. Syntypes, female, CHINA, Yunnan Province, Dali, on Armeniaca sp. Deposited in St. Petersburg: Zoological Museum, Academy of Science, Russia. Synonymised by Danzig (1970): 1016.

\section{Adult female (Figs $1 \&$ \& $6 d-f$ )}

Unmounted features and biology. Elongate oval, greenish-brown to purplish-brown, covered with fine white powdery wax, with 18 pairs of wax extensions around body margin. Feeds on the leaves and branches of its tree host. When matured, it produces a complete ovisac which covers the entire body except the apex of the head; ovisac about $7 \mathrm{~mm}$ long.

Instar diagnosis - Diagnosed by the following combination of features: (i) two or sometimes three circuli; (ii) oral-collar tubular ducts abundant, of two sizes, larger ones present on dorsum and smaller ones on venter; (iii) multilocular pores present; (iv) cerarii totalling 18 pairs, each cerarius with 2 cerarian setae (except $C_{17}$ and $C_{16}$ that each have 3 or 4 setae) plus 15-20 trilocular pores around each cerarian setae; and (v) with 9-segmented antennae. 
Description of slide-mounted adult female (Fig. 1) - Body elongate oval, 4.25-4.92 $\mathrm{mm}$ long, 2.74-0.64 mm wide (Fig. 4). Eye marginal, 50-60 $\mu \mathrm{m}$ wide. Antennae each 9 segmented, 560-610 $\mu \mathrm{m}$ long; apical segment 70-75 $\mu \mathrm{m}$ long, 30-32.5 $\mu \mathrm{m}$ wide. Clypeolabral shield 240-380 $\mu \mathrm{m}$ long, 240-270 $\mu \mathrm{m}$ wide. Labium 3 segmented, 200-250 $\mu \mathrm{m}$ long, 140-180 $\mu \mathrm{m}$ wide. Anterior spiracles $80.0-92.5 \mu \mathrm{m}$ long, 40-55 $\mu \mathrm{m}$ wide across atrium; posterior spiracles 95-120 $\mu \mathrm{m}$ long, 60-70 $\mu \mathrm{m}$ wide across atrium. Generally with 2 circuli (rarely 3), present between abdominal segments II and III, III and IV (and between IV and $\mathrm{V}$ when 3 present), largest circulus between III and IV, generally oval in shape, 225-285 $\mu \mathrm{m}$ wide, anterior circulus smaller, oval, $85-120 \mu \mathrm{m}$ wide. Legs well developed; hind trochanter + femur 400-440 $\mu \mathrm{m}$ long; hind tibia + tarsus 420-470 $\mu \mathrm{m}$ long; hind claw 30-40 $\mu \mathrm{m}$ long. Ratio of lengths of hind tibia + tarsus to hind trochanter + femur: 1.02-1.11:1; ratio of lengths of hind tibia to tarsus: 2.66-3.13:1; ratio of length of hind trochanter + femur to greatest width of femur: 4.00-5.12:1. Tarsal digitules setose, subequal in length, each 45-50 $\mu \mathrm{m}$ long. Claw digitules subequal in length, each 35-40 $\mu \mathrm{m}$ long, both capitate and thicker than tarsal digitules. Ostioles: both pairs present; each anterior ostiole with 28-36 trilocular pores and 6 or 8 setae (total for both lips); each posterior ostiole with 36-55 trilocular pores and 4 or 6 setae (total for both lips). Anal ring 90-110 $\mu$ m wide, with 6 anal-ring setae, each setae $165-190 \mu \mathrm{m}$ long.

Venter. Body setae slender, each 40-180 $\mu \mathrm{m}$ long, longest setae present medially on head; apical setae of anal lobe 230-275 $\mu \mathrm{m}$ long. Multilocular disc pores present, each 6-8 $\mu \mathrm{m}$ wide, in bands on abdominal segments as follows: 8-10 on posterior margin of segment III; $29-39$ on posterior margin of IV; $54-66$ on posterior margin of V; 65-86 on anterior and posterior margins of VI; 72-92 on anterior and posterior margins of VII; $60-78$ throughout VIII + IX. Quinquelocular pores each 5-6 $\mu \mathrm{m}$ in diameter, frequent on head and thorax and scattered on abdominal segments II and III. Trilocular pores each 4-5 $\mu \mathrm{m}$ in diameter, each slightly smaller than those on dorsum. Oral collar tubular ducts each 10.0-12.5 $\mu \mathrm{m}$ long, 3-4 $\mu \mathrm{m}$ wide, slightly smaller than ducts on dorsum, distributed on last abdominal segments as follows: $100-130$ on II-III, $53-65$ on IV; $68-71$ on V; $32-48$ on VI; 14-44 on VII; 20-24 on VIII + IX none on IX.

Dorsum. Derm membranous, with 18 pairs of cerarii around body margin, each cerarius with 2 cerarian setae, each 17.5-20.0 $\mu \mathrm{m}$ long, + 9-11 trilocular pores between cerarian setae, except $C_{16}$ with 3 (rarely 4) cerarian setae and 4-9 trilocular pores, and $C_{17}$ with 3 or 4 (usually 3) cerarian setae and 5-10 trilocular pores. Anal lobe cerarii each with 2 conical setae, each 25-30 $\mu \mathrm{m}$ long, + 25-31 trilocular pores and 3 auxiliary spine-like setae. Dorsal body setae spine like, each 7.5-15.0 $\mu \mathrm{m}$ long, scattered on head on thorax, in rows on abdominal segments. Trilocular pores each $3-5 \mu \mathrm{m}$ in diameter. Oral collar tubular ducts scattered throughout body surface, each duct 10.0-12.5 $\mu \mathrm{m}$ long, $4-5 \mu \mathrm{m}$ wide at distal, randomly distributed on head and thorax, but in bands on abdominal segments as follows: 74-101 on segments IV; 84-130 on segment V; 20-55 on VI; 18-39 on VII; and 14-18 on VIII + IX.

Comments - Generally with two circuli (rarely three), present between abdominal segments II and III, III and IV (but also between IV and V when third circulus present), largest circulus between III and IV generally oval in shape, anterior circulus smaller, oval. DANzIG (1980) indicated that the number of circuli in $\mathrm{Ph}$. aceris has great variation and that the number of circuli increased from two in the northwest of the range to five in the southeast of USSR. The North American population of Ph. aceris has two circuli (Kosz- 


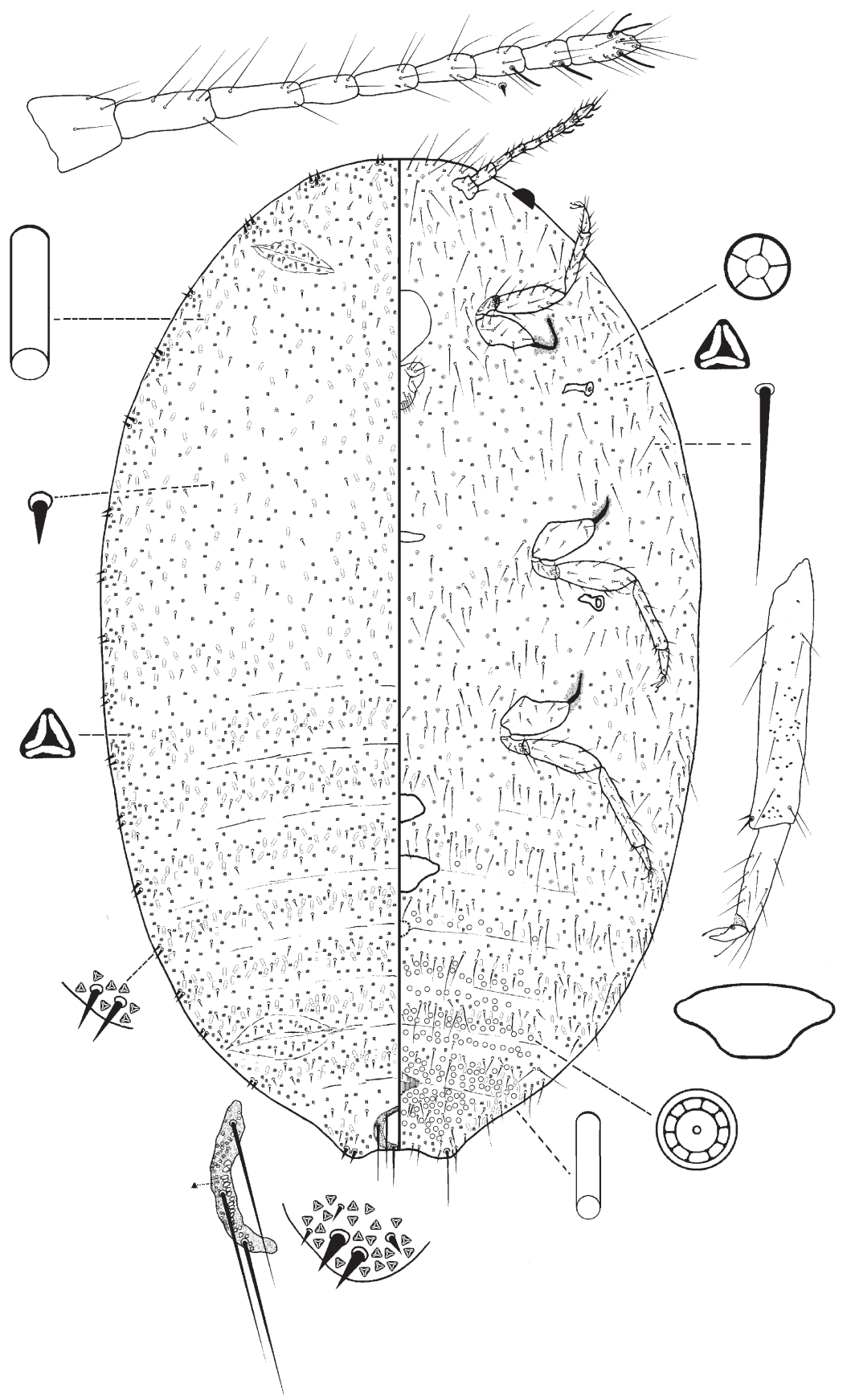

Fig. 1. Adult female of Phenacoccus aceris (after Kaydan et al. 2015). 
TARAB 1996). DANZig (1980) suggested that the North American population originated from Europe where the maple mealybug has two circuli. Similar variation in circulus number is observed in Ph. dearnessi, which has normally two circuli but rarely has one circuli (Miller \& Appleby 1971). Phenacoccus aceris and Ph. dearnessi are similar in having two circuli (in North America) and more than two conical setae on each anal lobe cerarii but these two species differ from each other in having numerous oral collar tubular ducts in $\mathrm{Ph}$. aceris (no oral collar tubular ducts in Ph. dearnessi) and a large ovisac which covers the entire dorsum except the head of Ph. aceris (Ph. dearnessi does not form a dorsal ovisac). Several other species such as Ph. transcaucasicus Hadzibejli, Ph. perillustris Borchsenius, Ph. tataricus Matesova, Ph. querculus (Borchsenius), Ph. silvanae Longo et Russo and Ph. alonim Ben-Dov are similar to Ph. aceris in morphology (in having large circuli), habitat (host plant species from Rosaceae and Fagaceae and living on branches of the host plants, and producing an ovisac on the leaves) and in their life cycles (in having one generation per year) in the Palaearctic region. Phenacoccus aceris differs from all these species in having two to five circuli (Ph. transcaucasicus Hadzibejli, Ph. perillustris Borchsenius, Ph. tataricus Matesova, Ph. querculus (Borchsenius), Ph. silvanae Longo et Russo and Ph. alonim Ben-Dov with one circulus).

\section{First-instar nymph (Figs 2 \& 7a)}

Unmounted features and biology. Elongate oval and yellow when alive. Settled nymphs covered by a thin layer of white powdery wax. For settlement, first-instar nymphs prefer mid veins of leaves and other hidden places on the leaf surface, such as under old ovisacs, and areas where two leaves touch and overlap, etc.

Instar diagnosis - Diagnosed by the following combination of features: (i) small body size; (ii) absence of circuli; (iii) presence of only one pair of oralcollar tubular ducts on head; (iv) absence of multilocular pores; (v) 18 pairs of cerarii, each cerarius with 2 cerarian setae with one trilocular pore between setae; and (vi) antennae and legs well developed and relatively large in relation to body size.

Description of slide-mounted first-instar nymph (Fig. 2) - Body elongate oval, 0.40-0.49 $\mathrm{mm}$ long, 0.20-0.25 mm wide (Fig. 2). Eye present marginally, 15-20 $\mu \mathrm{m}$ wide. Antenna 6 segmented, each 155-180 $\mu \mathrm{m}$ long; apical segment 60-70 $\mu \mathrm{m}$ long, 17.5-20.0 $\mu \mathrm{m}$ wide. Clypeolabral shield 60-70 $\mu \mathrm{m}$ long, 60-70 $\mu \mathrm{m}$ wide. Labium 3 segmented 35-45.0 $\mu \mathrm{m}$ long, 40-55 $\mu \mathrm{m}$ wide. Anterior spiracles $17.5-25.0 \mu \mathrm{m}$ long, 5.0-7.5 $\mu \mathrm{m}$ wide across atrium; posterior spiracles 20-25 $\mu \mathrm{m}$ long, 5.0-7.5 $\mu \mathrm{m}$ wide across atrium. Circulus absent. Legs well developed; hind trochanter + femur 90-95 $\mu \mathrm{m}$ long, hind tibia + tarsus 100-120 $\mu \mathrm{m}$ long, hind claw 15-20 $\mu \mathrm{m}$ long. Ratio of lengths of hind tibia + tarsus to hind trochanter + femur: 1.11-1.27:1; ratio of lengths of hind tibia to tarsus: $0.85-1.04: 1$, ratio of length of hind trochanter + femur to greatest width of femur 3.0-4:1. Tarsal digitules setose, subequal in 


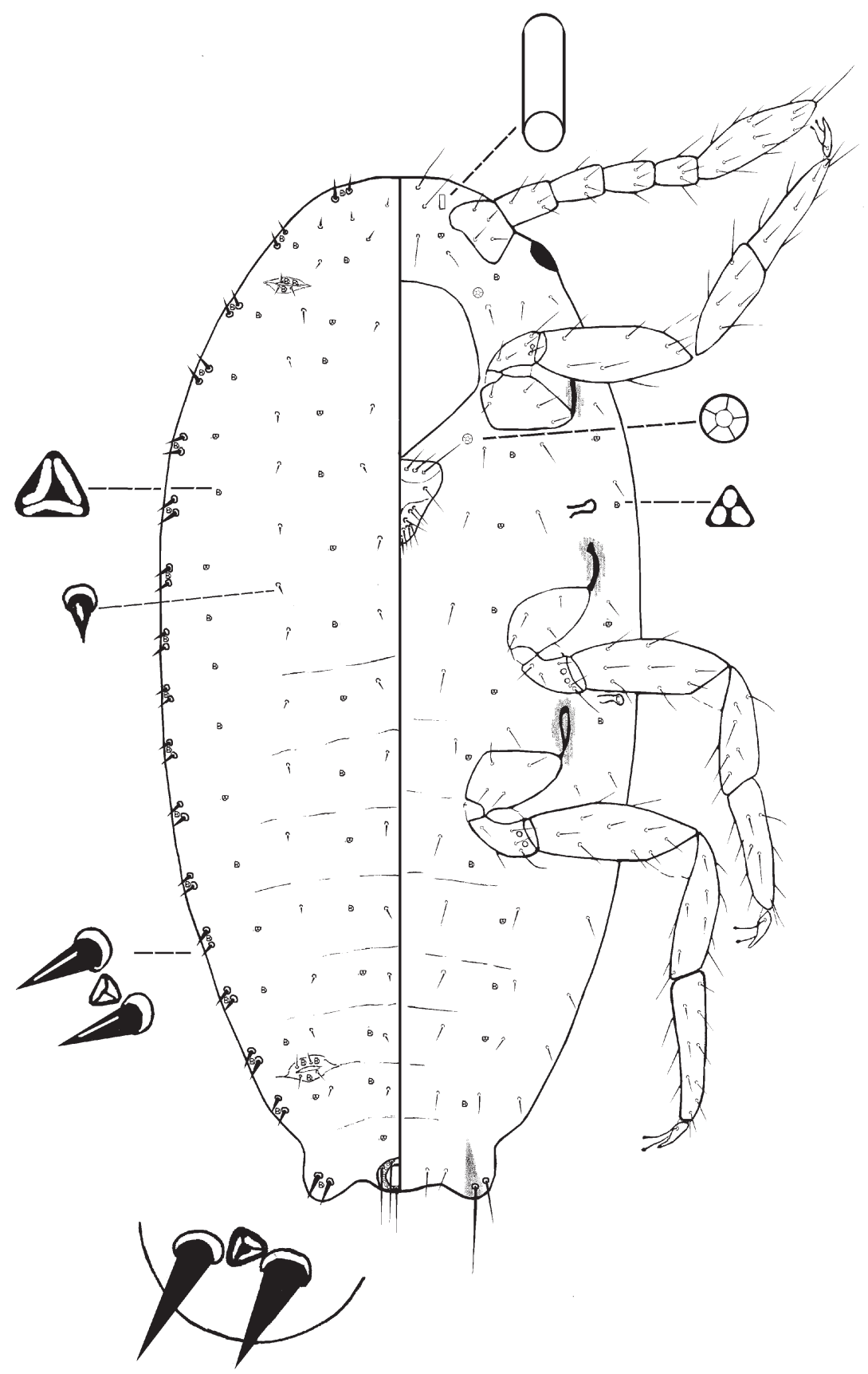

Fig. 2. First-instar nymph of Phenacoccus aceris. 
length, each one 15-20 $\mu \mathrm{m}$ long. Claw digitules each subequal in length, each 20-25 $\mu \mathrm{m}$ long, both capitate and thicker than tarsal digitules. Ostioles: both pairs present; each anterior ostiole with 1-3 trilocular pores and 1 setae (total for both lips); each posterior ostiole with 2-4 trilocular pores and 1-3 setae (total for both lips). Anal ring $25 \mu \mathrm{m}$ wide, with 6 anal-ring setae, each setae $35-45 \mu \mathrm{m}$ long.

Venter. Body setae slender, each 10-40 $\mu \mathrm{m}$ long, longest setae present medially on head; apical seta of anal lobe $90-100 \mu \mathrm{m}$ long. Multilocular pores absent. Trilocular pores each 2.5-3.75 $\mu \mathrm{m}$ diameter, present in one submedian longitudinal row. Quinquelocular pores each 3.8-4.0 $\mu \mathrm{m}$ in diameter; only near mouthparts, with 2 or 3 (generally 2) pairs of pores just anterior to mouthparts and other pair just posterior to mouthparts. Oral-collar tubular ducts small, of one size, each $7.5 \mu \mathrm{m}$ long, $2.5 \mu \mathrm{m}$ wide, generally only one at base of each antennal scape.

Dorsum. 18 pairs of cerarii present along body margin, each with 2 cerarian setae +1 trilocular pore. Anal lobe cerarii, each with 2 conical setae, 12.5-17.5 $\mu \mathrm{m}$ long, +1 trilocular pore. Dorsal body setae short and spine-like, each 5.0-7.5 $\mu \mathrm{m}$ long. Trilocular pores each 3-5 $\mu \mathrm{m}$ in diameter and slightly larger than trilocular pores on venter.

Comments - In this study we could not distinguish the sex in the first instar nymphs. There is some variation amongst first-instar nymphs in the number of trilocular pores on posterior abdominal segments, but this variation is continuous (not two discrete conditions) and not enough for sex determination. Miller and Appleby (1971) also could not distinguish the sex of the firstinstar nymphs of $P h$. dearnessi. They indicated that the first-instar nymphs of $\mathrm{Ph}$. dearnessi and $\mathrm{Ph}$. aceris are morphologically very similar but that $\mathrm{Ph}$. aceris differs from $\mathrm{Ph}$. dearnessi by having oral collar tubular ducts on the head near the antennae (absent in Ph. dearnessi). Ter-Grigorian (1973) described the body of the first-instar nymphs as having much larger dimensions, i.e., $0.7 \mathrm{~mm}$ long. Ter-Grigorian (1973) did not mention the host plant on which she collected her material, and this difference in size may be attributed to host plant differences or other ecological conditions.

\section{Second-instar female nymph (Figs 3 \& $7 b$ )}

Unmounted features and biology. Elongate oval and yellowish green; covered by a thin layer of fine white powdery wax, with 18 pairs of wax extensions around body margin. Feeds on leaf surfaces generally along midvein (like first-instar nymphs) during the vegetative season and then individuals migrate into crevices on the bark and tree trunk for hibernation. When the individuals reach the overwintering places they settled down and the nymphs produce small amounts of mealy secretion (Fig. 7b).

Instar diagnosis - Diagnosed by the following combination of features: (i) presence of a small circulus; (ii) presence of two sizes of oral-collar tubular ducts on body (dorsal ducts larger than those on venter); (iii) absence of multilocular pores; (iv) presence of 18 pairs of cerarii, each cerarius with 2 cerarian 


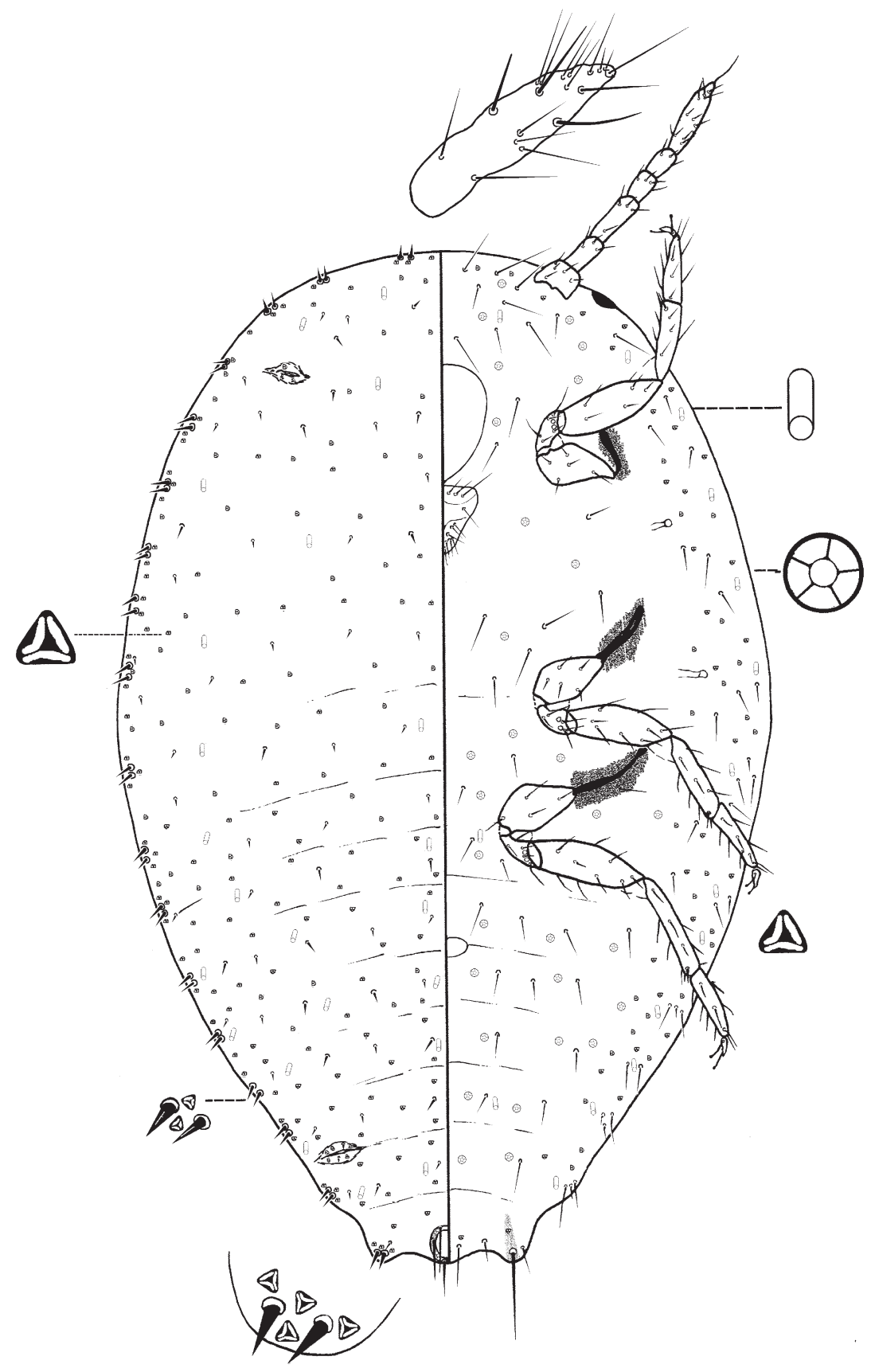

Fig. 3. Second-instar female nymph of Phenacoccus aceris. 
setae and 1 or 2 (generally 2) trilocular pores between setae; (v) antennae six segmented; and (vi) presence of numerous quinquelocular pores on venter.

Description of slide-mounted second-instar female (Fig. 3) - Body elongate oval, 0.67-1.30 mm long, 0.32-0.64 mm wide. Eyes present marginally, 22.5-25.0 $\mu \mathrm{m}$ wide. Antenna 6 segmented, 230-250 $\mu \mathrm{m}$ long; apical segment 70-80 $\mu \mathrm{m}$ long, 20.0-22.5 $\mu \mathrm{m}$ wide. Clypeolabral shield 95-110 $\mu \mathrm{m}$ long, 95-100 $\mu \mathrm{m}$ wide. Labium 3 segmented, 55-70 $\mu \mathrm{m}$ long, $60 \mu \mathrm{m}$ wide. Anterior spiracles $35 \mu \mathrm{m}$ long, 12.5-15.0 $\mu \mathrm{m}$ wide across atrium; posterior spiracles $37.5-40.0 \mu \mathrm{m}$ long, $10.0-12.5 \mu \mathrm{m}$ wide across atrium. Circulus oval, $20.0-37.5$ $\mu \mathrm{m}$ wide. Legs well developed: hind trochanter + femur 130-140 $\mu \mathrm{m}$ long, hind tibia + tarsus 155-160 $\mu \mathrm{m}$ long, hind claw 17.5-20.0 $\mu \mathrm{m}$ long. Ratio of lengths of hind tibia + tarsus to hind trochanter + femur: 1.19-1.23:1; ratio of lengths of hind tibia to tarsus: 1.06-1.23:1; ratio of length of hind trochanter + femur to greatest width of femur: $2.88-3.46: 1$. Tarsal digitules setose, subequal in length, each 15.0-17.5 $\mu \mathrm{m}$ long. Claw digitules subequal in length, each 17.5-22.5 $\mu \mathrm{m}$ long, capitate and thicker than tarsal digitules. Ostioles: both pairs present; each anterior ostiole with 4-7 trilocular pores and 1 or 2 setae (total for both lips); each posterior ostiole with 4-9 trilocular pores and 1 or 2 setae (total for both lips). Anal ring 40-45 $\mu \mathrm{m}$ wide, with 6 anal-ring setae, each setae $65-75 \mu \mathrm{m}$ long.

Venter. Body setae slender, 15-65 $\mu \mathrm{m}$ long, longest setae present medially on head; apical seta of anal lobe 130-170 $\mu \mathrm{m}$ long. Multilocular disc pores absent. Quinquelocular pores each $4-5 \mu \mathrm{m}$ in diameter, scattered throughout body surface. Trilocular pores each 2.5-4.0 $\mu \mathrm{m}$ in diameter, slightly smaller than those on dorsum, present on margin of submarginal area of body only. Oral-collar tubular ducts each 7.5-11.0 $\mu \mathrm{m}$ long, 2-3 $\mu \mathrm{m}$ wide, totalling 22-26, distributed as follows: $10-13$ on head and thorax, and 5-8 on abdominal segments II-III; 1 or 2 on IV and V; 0 or 1 on VI; $1-3$ on VII; 0 on VIII+IX.

Dorsum. Derm membranous, with 18 pairs of cerarii on body margin, each cerarius with 2 cerarian setae +2 (occasionally only one) trilocular pores. Anal lobe cerarii each with 2 conical setae, each setae 15-20 $\mu \mathrm{m}$ long, with 4-6 trilocular pores and 1 or 2 auxiliary setae. Dorsal body setae spine-like, each 5.0-7.5 $\mu \mathrm{m}$ long. Trilocular pores each $4-5 \mu \mathrm{m}$ in diameter, evenly scattered on dorsum. Oral collar tubular ducts scattered throughout body surface, totalling 26-29 on dorsum, each duct 10.0-12.5 $\mu \mathrm{m}$ long, 3-5 $\mu \mathrm{m}$ wide at distal end; ducts distributed as follows: 5-8 on head and thorax, and 6-11 on abdominal segments IIII, 3 or 4 on IV, 3 or 4 on V, 3 or 4 on V, 3 or 4 on VII; and absent on VIII+IX.

\section{Second-instar male nymph (Fig. 4)}

Unmounted features and biology. Elongate oval and yellowish green; covered in a thin layer of fine white powdery wax, with 18 pairs of wax extensions around body margin. Feeds on leaves during the vegetative season and then moves into crevices on the bark and tree trunk for hibernation. In the overwintering places, settled second-instar males produce a small amount of mealy secretion.

Instar diagnosis. Diagnosed by the following combination of features: (i) presence of a small circulus; (ii) presence of two sizes of oral-collar tubular ducts on body (dorsal ducts larger than those on venter); (iii) absence of multilocular pores; (iv) presence of 18 pairs of cerarii, each cerarius with 2 cerarian 
setae and 1 or 2 (generally 2) trilocular pores between setae; (v) antennae seven segmented and (vi) presence of numerous quinquelocular pores on venter.

Description of slide-mounted second-instar male (Fig. 3) - Body elongate oval, 0.68$1.25 \mathrm{~mm}$ long, 0.34-0.81 mm wide (Fig. 2). Eye marginal, 27.5-30.0 $\mu \mathrm{m}$ wide. Antenna 7 segmented, $270 \mu \mathrm{m}$ long; apical segment 45-50 $\mu \mathrm{m}$ long, $20 \mu \mathrm{m}$ wide. Clypeolabral shield 85-110 $\mu \mathrm{m}$ long, 85-100 $\mu \mathrm{m}$ wide. Labium 3 segmented, 65-70 $\mu \mathrm{m}$ long, 45-60 $\mu \mathrm{m}$ wide. Anterior spiracles $20-30 \mu \mathrm{m}$ long, 10.0-12.5 $\mu \mathrm{m}$ wide across atrium; posterior spiracles 30.0-42.5 $\mu \mathrm{m}$ long, 10.0-12.5 $\mu \mathrm{m}$ wide across atrium. Circulus oval, $40-50 \mu \mathrm{m}$ wide. Legs well developed: hind trochanter + femur 130-155 $\mu \mathrm{m}$ long, hind tibia + tarsus 150-190 $\mu \mathrm{m}$ long, hind claw 20.0-22.5 $\mu \mathrm{m}$ long. Ratio of lengths of hind tibia + tarsus to hind trochanter + femur: 1.03-1.33:1; ratio of lengths of hind tibia to tarsus: 1.38-1.56:1; ratio of length of hind trochanter + femur to greatest width of femur: 3.00-3.85:1. Tarsal digitules setose, subequal in length, each 20-30 $\mu \mathrm{m}$ long. Claw digitules subequal in length, each $20 \mu \mathrm{m}$ long, capitate and thicker than tarsal digitules. Ostioles: both pairs present; each anterior ostiole with 3-4 trilocular pores and 1 or 2 setae (total for both lips); each posterior ostiole with 4-9 trilocular pores and 1 or 2 setae (total for both lips). Anal ring $45 \mu \mathrm{m}$ wide, with 6 anal-ring setae, each seta $100 \mu \mathrm{m}$ long.

Venter. Body setae slender, 15-65 $\mu \mathrm{m}$ long, longest setae present medially on head; apical seta of anal lobe 160-170 $\mu \mathrm{m}$ long. Multilocular disc pores absent. Quinquelocular pores each $4-5 \mu \mathrm{m}$ in diameter, scattered throughout body surface. Trilocular pores each 2.5-4.0 $\mu \mathrm{m}$ in diameter, slightly smaller than those on dorsum, present on marginal or submarginal areas of the body only. Oral-collar tubular ducts each 10.0-12.5 $\mu \mathrm{m}$ long, 2.5-3.0 $\mu \mathrm{m}$ wide, totalling 20-25, distributed as follows: 6-9 on head and thorax, and 4-6 on abdominal segments II-III; 2 on IV and V; 0 or 1 on VI; 1 or 2 on VII; 0 on VIII.

Dorsum. Derm membranous, with 18 pairs of cerarii on body margin, each cerarius with 2 cerarian setae +2 (occasionally only one) trilocular pores. Anal lobe cerarii each with 2 conical setae, each setae 15-25 $\mu \mathrm{m}$ long, with 4-6 trilocular pores and 1 or 2 auxiliary setae. Dorsal body setae spine-like, each 5.0-7.5 $\mu \mathrm{m}$ long. Trilocular pores each $4-5 \mu \mathrm{m}$ in diameter, evenly scattered on dorsum. Oral collar tubular ducts scattered throughout body surface, totalling 58-65 on dorsum, each duct 10.0-12.5 $\mu \mathrm{m}$ long, 3-5 $\mu \mathrm{m}$ wide at distal end; ducts distributed as follows: $22-24$ on head and thorax, and 17-19 on abdominal segments I-III, 6 on IV, 3 or 4 on V, 4 or 5 on V, 3 or 4 on VI, 3-5 on VII and 2 on VIII+IX.

Comments - Miller and Denno (1977) reported that male specimens of most mealybugs grow into the adult stage in a thin felt-like cover, made of a white mealy secretion produced at the end of the second-instar nymphal stage. The production of a felt-like cover was hitherto only known to occur in the males. However, in the case of Ph. aceris, at the end of the second instar both sexes produce a mealy secretion similar to a felt-like cover as occurs in members of the Acanthococcidae and related families, which is secreted by the many dorsal tubular ducts on the dorsum. A similar situation was observed by Miller and Appleby (1971) for Ph. dearnessi. They indicated that second-instar females of Ph. dearnessi are found on the lower parts of the leaf surface generally along the midveins during the summer season and then migrate to crevices, roughened areas or loosened bark on branches or the trunk 


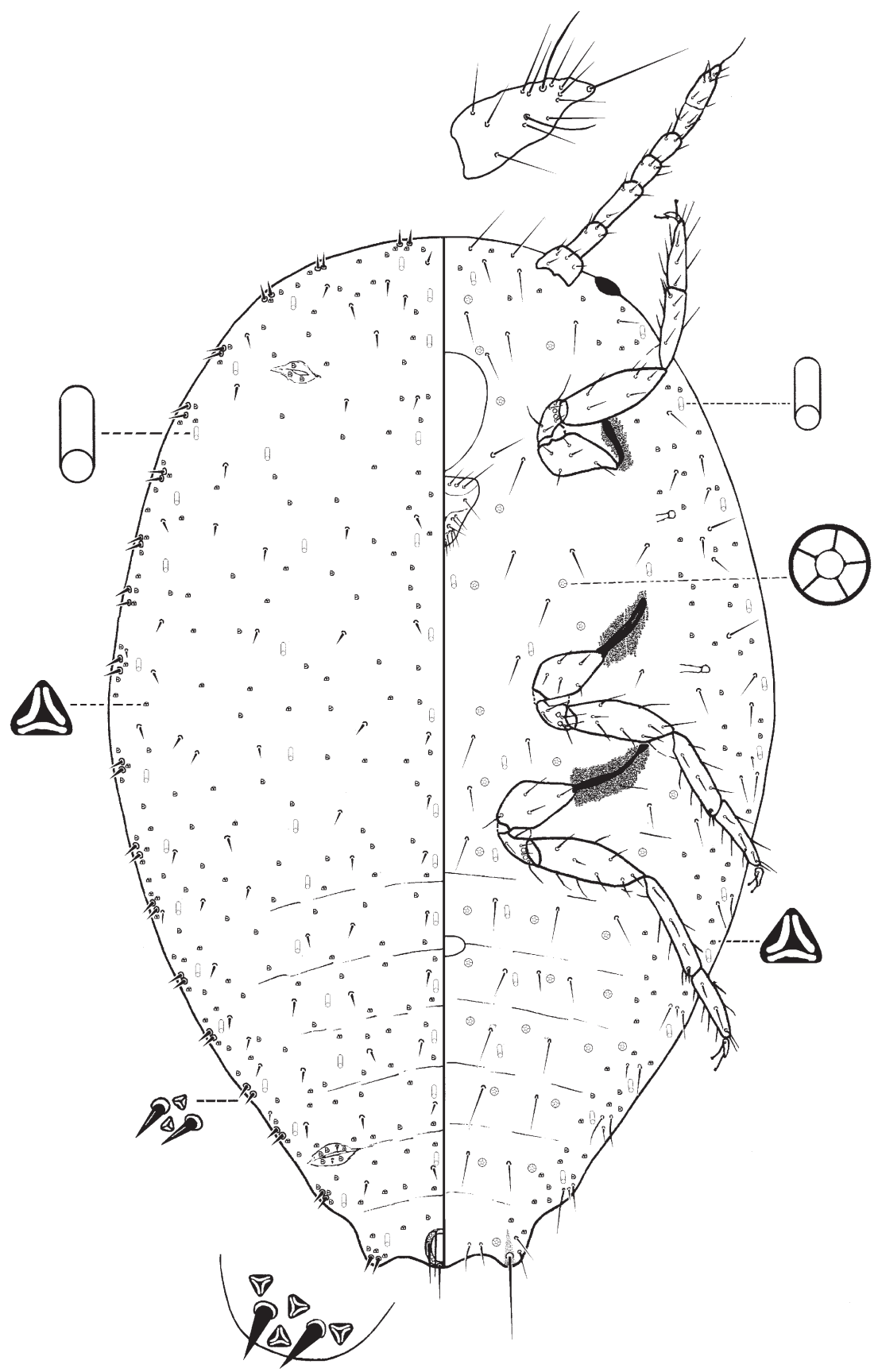

Fig. 4. Second-instar male nymph of Phenacoccus aceris. 
of plants and after settling they produced small amounts of mealy secretion on the dorsum. This mealy structure was observed on both female and male individuals (Miller \& Appleby 1971). We assume that migration to crevices, roughened areas or loosened bark on branches or the trunk of trees and the production of small amounts of mealy secretion on the dorsum of both female and male after settling occurs in many Phenacoccus species that have only one generation per year, such as Ph. transcaucasicus Hadzibejli, and Ph. querculus (Borchsenius), most of which are tree feeding mealybugs, and differ from other Phenacoccus species which have more than one generation per year, such as Ph. solenopsis Tinsley, Ph. madeirensis Green and Ph. solani Ferris.

It should be noted that some second-instar nymphs were found among the overwintering population of Ph. aceris, however, when these specimens were slide-mounted, it was found that they were parasitized. Therefore, these parasitized second-instar nymphs were not included in the evaluation.

Ter-Grigorian (1973) described the body of the second-instar nymphs as being larger, i.e., $1.1 \mathrm{~mm}$ long and $0.6 \mathrm{~mm}$ wide. TER-Grigorian (1973) did not mention the host plant and so this difference in size may be attributable to host plant differences, other ecological conditions or calibration differences of the microscope.

\section{Female third-instar nymph (Figs $5 \& 7 c$ )}

Unmounted features and biology. Elongate oval and light green, covered by fine white powdery wax produced by trilocular pores; with 18 pairs of wax extensions around body margin. The third-instar female overwinters in a felt-like test in bark cavities and other hidden places on its tree host.

Instar diagnosis - Diagnosed by the following combination of features: (i) one circulus; (ii) one size oral-collar tubular ducts, on venter only; (iii) absence of multilocular pores; (iv) presence of 18 pairs of cerarii, each cerarius with 2 cerarian setae +2 or 3 (generally 2) trilocular pores between setae; (v) 7-segmented antennae; and (vi) presence of numerous quinquelocular pores on venter.

Description of slide-mounted third-instar female (Fig. 4) - Body elongate oval, 1.00$1.24 \mathrm{~mm}$ long, 0.57-0.64 mm wide. Eyes present marginally, 25-40 $\mu \mathrm{m}$ wide. Antennae each 7 segmented, 310-370 $\mu \mathrm{m}$ long; apical segment 85-95 $\mu \mathrm{m}$ long, 25-325 $\mu \mathrm{m}$ wide. Clypeolabral shield 135-145 $\mu \mathrm{m}$ long, 135-155 $\mu \mathrm{m}$ wide. Labium 3 segmented, 100-110 $\mu \mathrm{m}$ long, 80-110 $\mu \mathrm{m}$ wide. Anterior spiracles each 50-60 $\mu \mathrm{m}$ long, 20-25 $\mu \mathrm{m}$ wide across atrium; posterior spiracles each 55-63 $\mu \mathrm{m}$ long, 20-25 $\mu \mathrm{m}$ wide across atrium. Circulus oval, 55-85 $\mu \mathrm{m}$ wide. Legs well developed; hind trochanter + femur 170-220 $\mu \mathrm{m}$ long; hind tibia + tarsus 210-260 $\mu \mathrm{m}$ long; hind claw 22.5-30.0 $\mu \mathrm{m}$ long. Ratio of lengths of hind tibia + tarsus to hind trochanter + femur: 1.15-1.23:1; ratio of lengths of hind tibia to tarsus: $1.35-1.50: 1$; ra- 


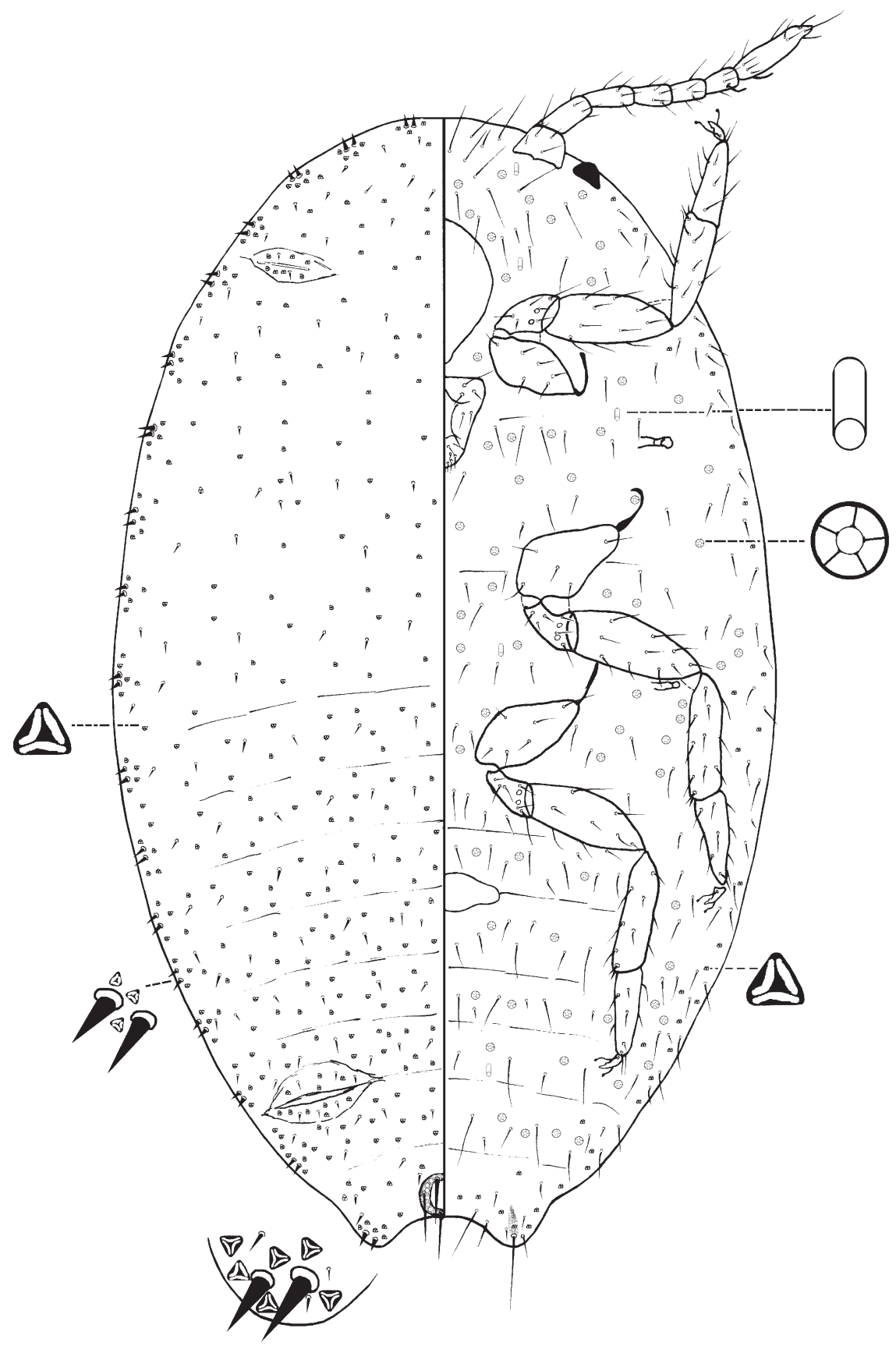

Fig. 5. Third-instar female nymph of Phenacoccus aceris. 


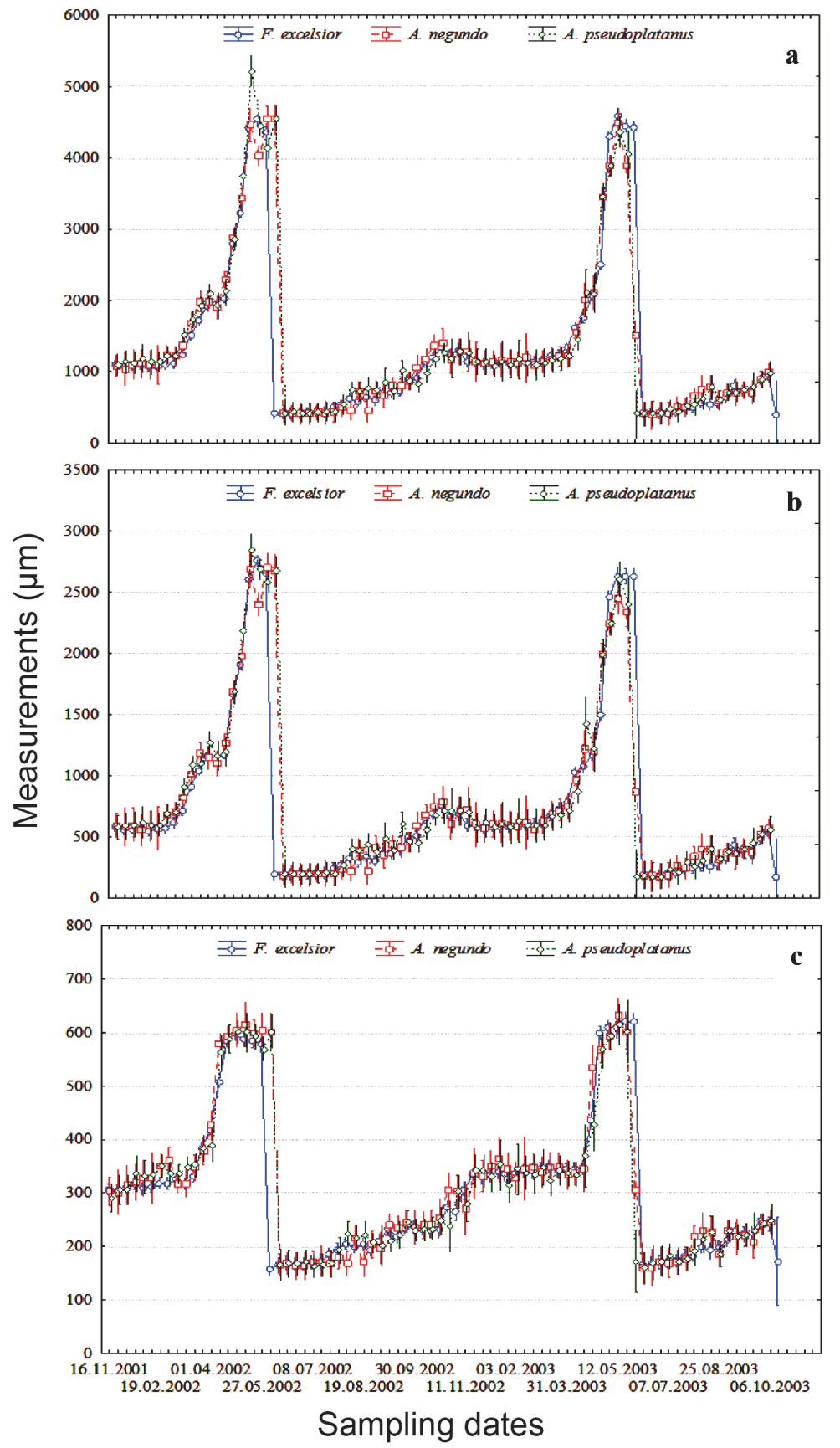

Fig. 6. Mean measurements (+/-SE) of body width, body length and antennal length of 20 specimens of Ph. aceris on Acer negundo, A. pseudoplatanus and Fraxinus excelsior. 

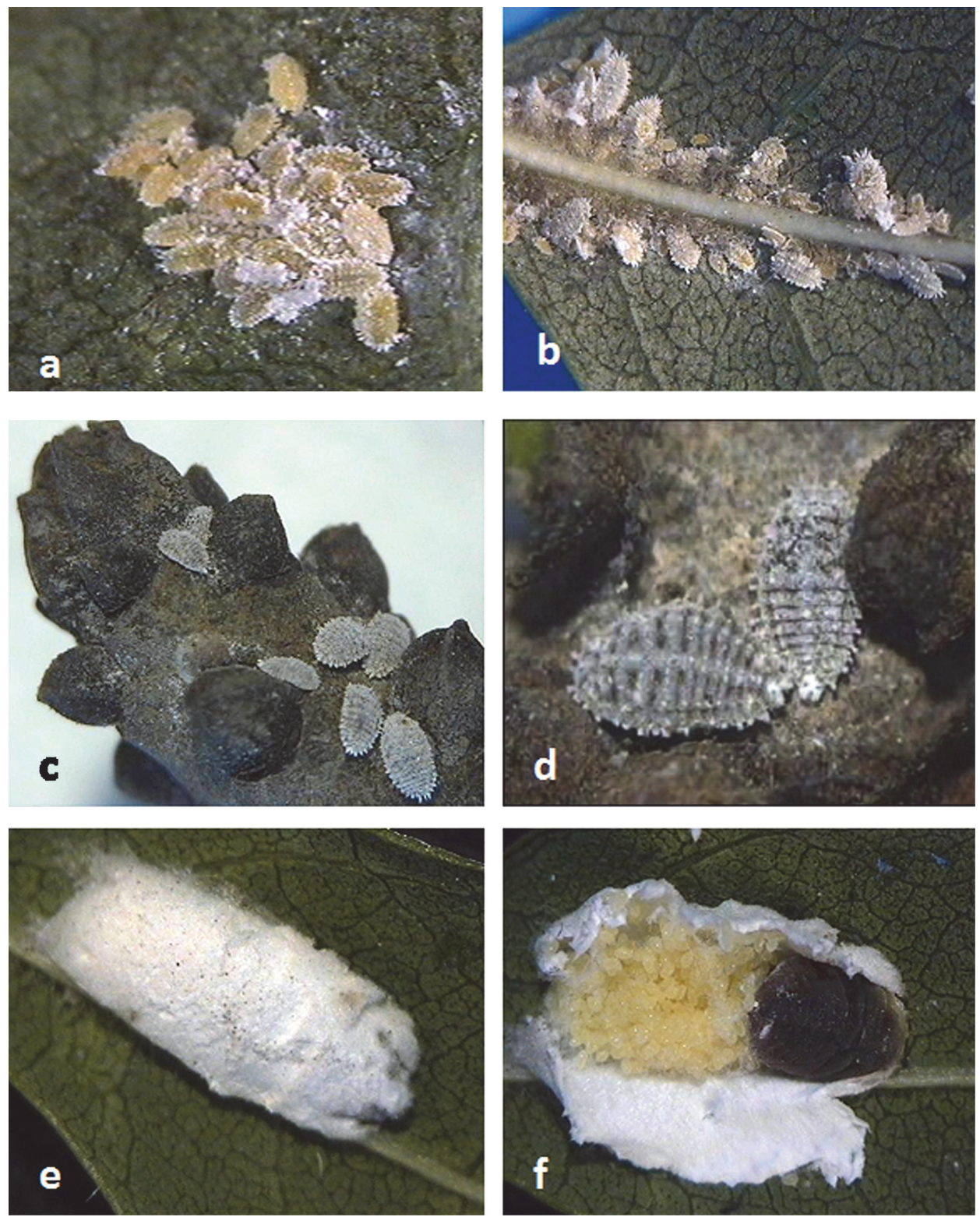

Fig. 7. Developmental stages of Phenacoccus aceris: a) first-instar nymphs settled on leaf surface; b) second-instar female nymphs against leaf midrib; c) third-instar female nymphs on twig apex; d) young adult female on twigs; e) adult female on lower leaf surface beneath ovisac; f) gravid adult female with ovisac cut opened to show its eggs. (Photos by M. B. Kaydan) 
tio of length of hind trochanter + femur to greatest width of femur: 2.71-3.45:1. Tarsal digitules setose, subequal in length, each 25-35 $\mu \mathrm{m}$ long. Claw digitules subequal in length, each 22.5-30.0 $\mu \mathrm{m}$ long; both capitate and thicker than tarsal digitules. Ostioles: both pairs present; each anterior ostiole with 7-9 trilocular pores and 3 or 4 setae (total for both lips); each posterior ostiole with $8-11$ trilocular pores and 3 or 4 setae (total for both lips). Anal ring $55 \mu \mathrm{m}$ wide, with 6 anal-ring setae, each setae 90-110 $\mu \mathrm{m}$ long.

Venter. Body setae slender, 25-80 $\mu \mathrm{m}$ long, longest setae present medially on head; apical seta of anal lobe 137.5-170.0 $\mu \mathrm{m}$ long. Multilocular disc pores absent. Quinquelocular pores each $4-5 \mu \mathrm{m}$ in diameter, scattered throughout body surface. Trilocular pores each 2.5-3.5 $\mu \mathrm{m}$ in diameter on submarginal areas of body. Oral-collar tubular ducts each 8.0-12.5 $\mu \mathrm{m}$ long, 2.5-3.0 $\mu \mathrm{m}$ wide, totalling 7-9, scattered throughout venter.

Dorsum. Derm membranous, with 18 pairs of cerarii around body margin, each cerarius with 2 cerarian setae +2 or 3 (generally 2) trilocular pores between setae. Anal lobe cerarii each with 2 conical setae, each cerarian setae 17.5-22.5 $\mu \mathrm{m}$ long, with 11-14 trilocular pores and 3 auxiliary setae. Dorsal body setae spine-like, each 6-10 $\mu \mathrm{m}$ long. Trilocular pores each 3-5 $\mu \mathrm{m}$ in diameter. Oral-collar tubular ducts absent.

Comments. The females of Ph. aceris overwinter as third-instar nymphs in felt-like sacs, which are produced by the second-instar nymphs in secretive places on the stem, thick branches and other woody parts of the trees. It was observed that as soon as the second-instar nymphs finished producing the mealy secretion similar to felt-like covers the individuals moulted to either third-instar female or prepupal stages. Then the male maple mealybug overwinters as pupae in the same area together with female third-instar nymphs. Miller and Appleby (1971) indicated that third-instar females of Ph. aceris and Ph. dearnessi are similar in having one small circulus and in lacking oral collar tubular ducts on the dorsum. They indicated that the most discrete difference was the number of cerarii; Ph. dearnessi possesses 5-11 pairs whereas $P h$. aceris 15-18 pairs (Miller \& Appleby 1971). In this study, we observed only 18 pairs of cerarii in all populations.

\section{KEY TO THE INSTARS OF PHENACOCCUS ACERIS}

1 Antennae 9 segmented; with 2 or 3 circuli; vulva present Adult female

- Antennae with 6 or 7 segments; with $0-1$ circulus present, vulva absent 2

2 Circuli present; with 2 or more trilocular pores between cerarian setae on each cerarius

- Circuli absent; each cerarius with a single trilocular pore between cerarian setae

First-instar nymph

3 Oral collar tubular ducts of 2 sizes on body (ducts on dorsum larger than those on venter) 
- Oral collar tubular ducts absent on dorsum third-instar female nymph

4 Antennae 7 segmented; oral-collar tubular ducts present on dorsal abdominal segments VIII+IX Second-instar male nymph

- Antennae 6 segmented; oral-collar tubular ducts absent on dorsal abdominal segments VII+VIII+IX Second-instar female nymph

\section{FIELD OCCURRENCE OF DIFFERENT STAGES IN EACH POPULATION}

The rate of development of $\mathrm{Ph}$. aceris was similar on all three host-plant species in both seasons (Fig. 6). During the winter months (mid-November to March), there were no significant changes in size for any of the measurements (average body length, body width and antennal length). Presumably the third-instar nymphs do not feed during this time when the trees are dormant. From mid-March, with increasing temperatures, the host plants come out of dormancy, the sap begins to flow and the insects start to feed and continue to grow. An exponential growth rate was noticed from mid-May when the adult females reached their maximum body length and body width on all three host plants ( $1100 \mu \mathrm{m}$ to $5500 \mu \mathrm{m}$ long; $550 \mu \mathrm{m}$ to $2500 \mu \mathrm{m}$ wide) (Fig. 6). When the insects reached the adult stage, the growth rate became stable for some weeks and during this period the adult female population starts to lay eggs. Once the eggs hatch (from about mid-June) the insect growth is almost linear until the cold winter months when the growth rate stops for the winter (Fig. 6).

The occurrence of the egg stage in the population through the life cycle of Ph. aceris was 42 days in 2002, however, the occurrence of the egg stage was much shorter in 2003 (Table 1).

Badowska-Czubik and Suski (1990) reported that the first egg of Ph. aceris reared on apple in Poland was observed on April 28 in 1984, and the last egg on May 12 in 1982. In addition, DüzgüNEş (1982) reported that Ph. aceris started laying eggs at the end of April and eggs started hatching after 29-34 days in Ankara, Turkey. On the other hand, in Germany, Schmutterer (1952) observed that eggs of the maple mealybug, which were laid at the middle of April, started to hatch 30 days after being laid.

While the first-instar nymphs of Ph. aceris in 2002 were present in the population around 91-119 days on different host plant species (Table 1), in 2003, first-instar nymphs of the maple mealybug were present for 105 days in the population feeding on A. pseudoplatanus, 112 days in the population feeding on $A$. negundo, and 119 days in the population feeding on F. excelsior (Table 1). 


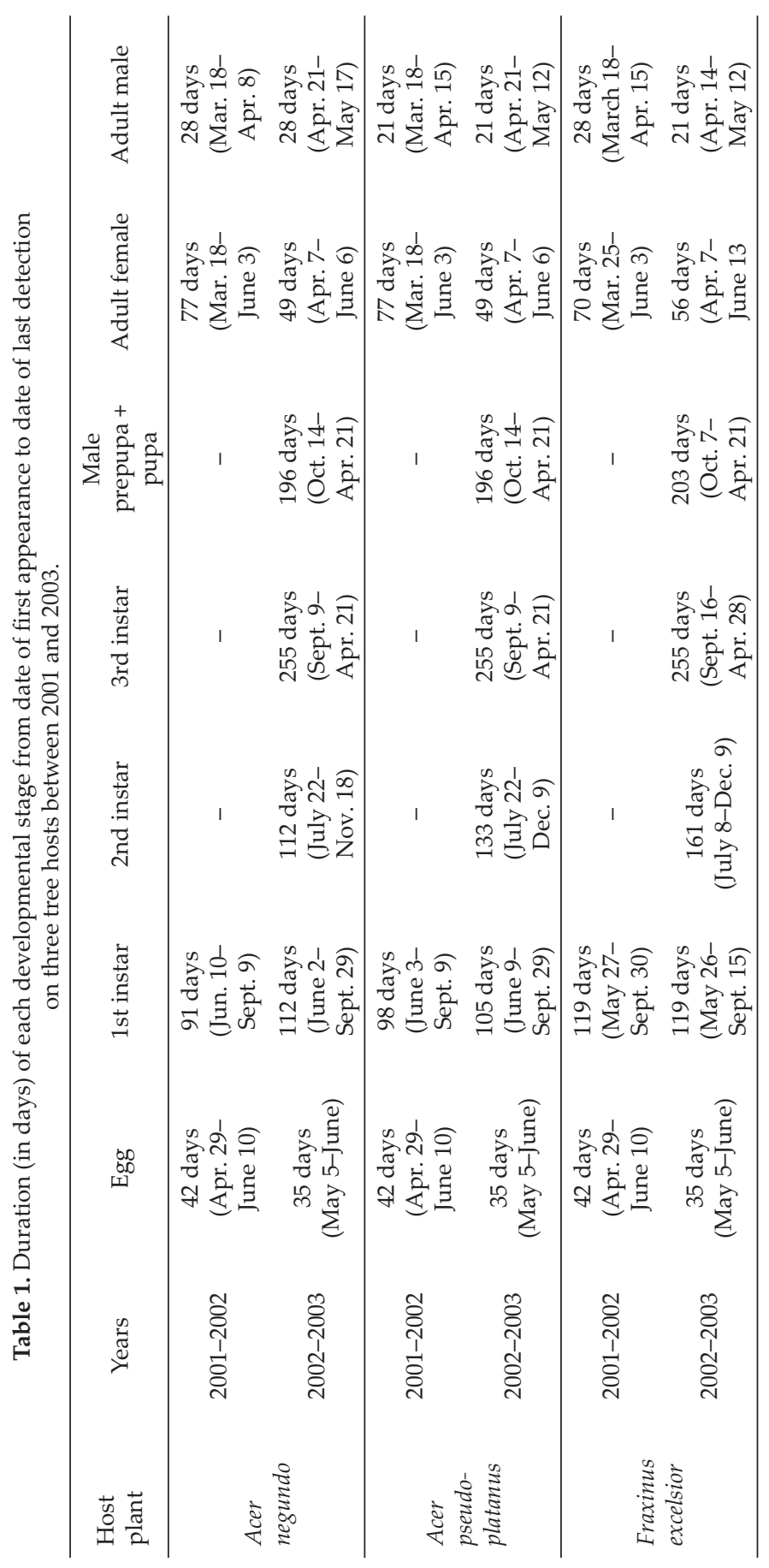


First observations of the first-instar nymphs of the maple mealybug in different regions and on different host plants have been reported by different researchers, namely, at end of May and beginning of June on different host plants at Ankara (Düzgüneş 1982); on apple in Poland (BADowska-Czubıк \& Suski 1990); at the beginning of July on different host plants in the Primorye region; at the end of July at Sakhalin and Kunashir region of USSR (DANZIG 1990); at the end of May in central Europe (Kosztarab \& KozÁr 1988); in the middle of May on grape vine in Germany (Hofmann 2002); and at the end of July in North America (Kosztarab 1996).

Second-instar nymphs of Ph. aceris occurred between July 8 and December 9 (161 days) in the population feeding on F. excelsior (Fig. 6); between July 22 and November 18 (112 days) in the population feeding on $A$. negundo; and between July 22 and December 9 (133 days) in the population feeding on $A$. pseudoplatanus (Table 1).

Hofmann (2002) reported that second-instar nymphs could be seen between mid-June until the end of October in Germany.

The female third-instar nymphs could be found for 255 days on all host trees, and this was the longest period of occurrence of all female stages. On the other hand, the longest occurrence period for males of Ph. aceris was the prepupal + pupal stage, which lasted for 196 days in the population on Acer spp., and for 203 days on the population on F. excelsior (Table 1).

DANZIg (1990) and Schmutterer (1952) reported that Ph. aceris overwintered as third-instar nymphs and prepupae + pupae and that second-instar nymphs started to move to the stem of the trees to overwinter in mid-September.

The first adult females were observed on mid-March in 2002, whereas this stage was observed at the end of April in 2003 (Table 1). It was determined that there was a big difference on the occurrence of adult females between the two years. The reason for these phenological differences between 2002 and 2003 may be attributed to abiotic environmental conditions, such as temperature. Indeed, the average temperature in March 2002 was much higher than that of March 2003 (longer term cold weather was observed in 2003). In 2002, the temperature started to get warmer at the end of February, a month earlier than 2003. Environmental conditions such as temperature and humidity may affect the behaviour, dispersal, population dynamics, life cycle and developmental rate of scale insects (Beardsley \& Gonzales 1975, Miller \& Kosztarab 1979, Kosztarab \& Kozár 1988, McClure 1990a,b, Chong et al. 2003).

In 2002, adult males were observed for 21 days in the population of $A$. pseudoplatanus and F. excelsior; and were observed for 28 days in the A. negundo population (Table 1). This stage was present for 21 days in the populations feeding on A. pseudoplatanus and F. excelsior, and 28 days in the population feeding on A. negundo in 2003 (Table 1). 
DüZGÜNEŞ (1992) reported that adult males completed their development before the adult females and appeared in April. Hoffmann (2002) and ScHmuTERRER (1952) reported that males appear in mid-March in Germany.

Acknowledgements - The authors offers many thanks to Chris Hodgson (Department of Biodiversity and Biological Systematics, The National Museum of Wales, Cardiff, UK), for spending valuable time on the manuscript and commenting on the different instars of $P h$. aceris in the paper. Special thanks to Dr. Penny Gullan (Division of Evolution, Ecology \& Genetics, Research School of Biology, The Australian National University, Canberra, Australia) for her comments, suggestions and information provided which greatly improved the manuscript. Thanks also to anonymous reviewers whose comments helped improved the manuscript. This study was supported financially by YYU Research Foundation.

\section{REFERENCES}

Badowska-Czubik, T. \& Suski, Z. W. (1990) Biology of Phenacoccus aceris and its parasite Anagyrus quercicola. Pp. 143-144. In: Proceedings of the Sixth International Symposium of Scale Insect Studies, Part II. Cracow, Poland: August 6-12, 1990. Agricultural University Press, Cracow.

Bartlett, B. R. (1978) Pseudococcidae. Pp. 137-170. In: Clausen, C. P. (ed.): Introduced parasites and predators of arthropod pests and weeds: a world review. Agricultural Research Service, United States Department of Agriculture, Washington, D.C.

Beardsley, J. W. \& Gonzalez, R. H. (1975) The biology and ecology of armored scales. Annual Review of Entomology 20: 47-73. doi: 10.1146/annurev.en.20.010175.000403

Bodenheimer, F. S. (1953) The Coccoidea of Turkey III. Revue de la Faculté des Sciences de l'Université d'Istanbul (Ser. B) 18: 91-164.

Ben-Dov, Y., Miller, D. R. \& Gibson, G. A. P. (2015) ScaleNet: a database of the scale insects of the world. Scales in a Region Query Results. 20 March, 2008. http://www.sel. barc.usda.gov/scalenet/scalenet.htm

Chong, J., Oetting, R. D. \& Iersel, M. W. (2003) Temperature effects on the development, survival, and reproduction of the madeira mealybug, Phenacoccus madeirensis Green (Hemiptera: Pseudococcidae), on Chrysanthemum. Annals of the Entomological Society of America 96(4): 539-543. doi: 10.1603/0013-8746(2003)096[0539:TEOTDS]2.0.CO;2

DANZIG, E. M. (1990) Coccids of the Far-Eastern USSR (Homoptera: Coccinea). Phylogenetic analysis of coccids in the world fauna. Oxonian Press, New Delhi, India, $450 \mathrm{pp}$.

Düzgüneş, Z. (1982) Mealybugs (Homoptera: Pseudococcidae) of Turkey. Ankara University Agriculture Faculty. Publications No. 836, 54 pp.

Ferris, G. F. (1950) Atlas of the scale insects of North America. (ser. 5). The Pseudococcidae (Part I). Stanford University Press, Palo Alto, California, 278 pp.

Gullan, P. J. (2000) Identification of the immature instars of mealybugs (Hemiptera: Pseudococcidae) found on citrus in Australia. Australian Journal of Entomology 39: 160-166. doi: 10.1046/j.1440-6055.2000.00171.x

Hoffmann, H. (2002) Schildläuse im Weinbau und ihre antagonisten. (Unpublished Ph.D. thesis), $176 \mathrm{pp}$. 
Kaydan, M. B., Kilinçer, N. \& KozÁr, F. (2005) Studies on Pseudococcidae (Homoptera: Coccoidea) fauna urban ecosystem of Ankara Province, Turkey. Bolletino di Zoologia Agraria e di Bachicoltura Ser. II. 37(2): 85-95.

Kaydan, M. B., KozÁr, F. \& Hodgson, C. (2015) A review of the phylogeny of Palaearctic mealybugs (Hemiptera: Coccomorpha: Pseudococcidae). Arthropod Systematics and Phylogeny 73(1): 175-195.

Kaydan, M. B., ÜlgentüRK, S., ZeKI, C., Toros, S. \& GÜRKAn, M. O. (2004) Studies on Pseudococcidae (Homoptera: Coccoidea) fauna of Afyon, Ankara, Burdur and Isparta Provinces, Turkey. Turkish Journal of Zoology 28(3): 219-224.

Kosztarab, M. \& KozÁr, F. (1988) Scale insects of Central Europe. Akadémiai Kiadó, Budapest, $456 \mathrm{pp}$.

Kosztarab, M. (1996) Scale insects of northeastern North America. Identification, biology, and distribution. Virginia Museum of Natural History, Martinsburg, Virginia, $650 \mathrm{pp}$.

McClune, M. S. (1990a) Seasonal history. Pp. 315-318. In: Rosen, D. (ed.): Armored scale insects, their biology, natural enemies and control. World Crop Pests, Vol. 4A. Elsevier, Amsterdam, The Netherlands.

MCClure, M. S. (1990b) Influence of environmental factors. Pp. 319-330. In: Rosen, D. (ed.): Armored scale insects, their biology, natural enemies and control. World Crop Pests, Vol. 4 A. Elsevier, Amsterdam, The Netherlands.

Miller, D. R. \& Appleby, J. E. (1971) A redescription of Phenacoccus dearnessi (Homoptera: Coccoidea: Pseudococcidae). Annals of the Entomological Society of America 64: 1342-1357. doi: 10.1093/aesa/64.6.1342

Miller, D. R. \& Denno, R. F. (1977) A new genus and species of mealybug with considerations of morphological convergence in three arboreal species. Systematic Entomology 2: 111-157.

Miller, D. R. \& Kosztarab, M. (1979) Recent advances in the study of scale insects. Annual Review of Entomology 24: 1-27 doi: 10.1146/annurev.en.24.010179.000245

Newstead, R. (1903) Monograph of the Coccidae of the British Isles. Vol. 2. Ray Society, London, 273 pp.

PAIK, W. H. (1978) Illustrated flora and fauna of Korea. Insecta (VI). No. 22. Ministry Education, Samhwa Publ. Co. Ltd., Korea, 481 pp.

Schmutterer, H. (1952) Über drei neue an Gräsern lebende Schildlausarten der deutschen Fauna. Beiträge zur Entomologie, Berlin 2: 554-566.

Sforza, R., Boudon-Padieu, E. \& Greif, C. (2003) New mealybug species vectoring grapevine leaf roll-associated viruses-1 and -3 (GLRaV-1 and -3). European Journal of Plant Pathology 109: 975-981.

Tereznikova, E. M. (1975) Coccids. The "Fauna of Ukraine". Akademii Nauk Ukrains'koi SSR Instituta Zoologicheskogo 20(Pt. 18), 295 pp. [in Russian]

Ter-Grigorian, M. A. (1973) Fauna of the Armenian SSR: Proboscis insects (Coccoidea, Pseudococcidae). Akademii Nauk Arm. SSR., Erevan, 246 pp. [in Russian]

Revised version received March 16, 2015, accepted May 17, 2015, published August 14, 2015 


\section{SYNTHESYS}

\section{Synthesis of systematic resources}
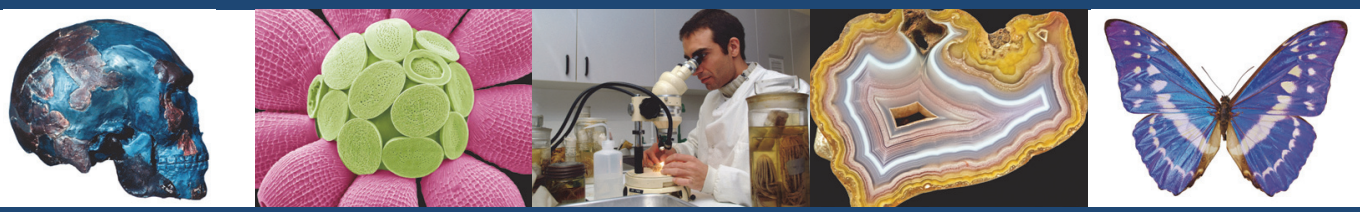

\section{Access to research infrastructures}

SYNTHESYS offers unique research opportunities to scientists from all over Europe.

Access is provided to:

- European collections comprising more than half of the world's natural history specimens

- world class libraries

- state-of-the-art facilities including imaging, chemical, and molecular laboratories

- support from in-house scientists, including researchers, facilities staff, and collections managers

Participation is free of charge and is provided on the basis of scientific excellence of a proposal, reviewed by a Selection Panel. Priority is given to new users. A typical project is 1-6 weeks in duration.

The 16 partner institutions offer access via 11 national Taxonomic Access Facilities (TAFs).

AT-TAF: Naturhistorisches Museum, Vienna

BE-TAF: Royal Belgian Institute of Natural Sciences, Brussels; Royal Museum for Central Africa, Tervuren

CZ-TAF: Národni Muzeum, Prague

DE-TAF: Botanischer Garten und Botanisches Museum Berlin-Dahlem, Berlin; Museum für Naturkunde, Berlin

DK-TAF: University of Copenhagen

ES-TAF: Museo Nacional de Ciencias Naturales \& Real Jardín Botánico, Madrid
FR-TAF: Muséum National d'Histoire Naturelle, Paris

GB-TAF: Natural History Museum, London; Royal Botanic Gardens, Kew; Royal Botanic Garden, Edinburgh

HU-TAF: Hungarian Natural History Museum, Budapest

NL-TAF: Naturalis Biodiversity Center, Leiden

SE-TAF: Naturhistoriska riksmuseet, Stockholm

SYNTHESYS will provide finance for:

a research costs

a per diem contribution towards living costs

international travel and accommodation

u logistical support at the host institution

Contact SYNTHESYS for details of the online application process and deadlines:

Annual Calls for proposals in October (2013 - 2016)

Visits will be scheduled between January 2014 and August 2017

email: synthesys@nhm.ac.uk

www.synthesys.info

SYNTHESYS is a project supporting an integrated European infrastructure for natural history collections funded via the EC Research Infrastructure Activity, FP7 Programme

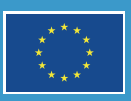

